\title{
Optimum dose of sulphasalazine for maintenance treatment in ulcerative colitis
}

\author{
A K AZAD KHAN, D T HOWES, J PIRIS, AND S C TRUELOVE \\ From the Nuffield Department of Clinical Medicine and the Gibson Laboratories, Radcliffe Infirmary, Oxford
}

SUMMARY Sulphasalazine is widely used in the maintenance treatment of ulcerative colitis but the optimum dose is not known. In the present study, 170 patients were allotted at random to three treatment groups, in which the daily dose was 1,2 and $4 \mathrm{~g}$ respectively, and the trial period of treatment lasted for six months. A daily dose of $2 \mathrm{~g}$ was found to be much more efficacious than $1 \mathrm{~g}$. A daily dose of $4 \mathrm{~g}$ was more efficacious than $2 \mathrm{~g}$ but at the price of fairly frequent symptomatic side-effects. Haematological abnormalities were observed at all dosage levels, but they occurred chiefly among the patients on $4 \mathrm{~g}$ daily. Both the symptomatic and the haematological side-effects were usually associated with high concentrations of serum sulphapyridine and these high levels occurred chiefly among the slow acetylators. It is concluded that, for general use, a daily dose of $2 \mathrm{~g}$ sulphasalazine is satisfactory for the maintenance treatment of ulcerative colitis. If a patient does not do well on $2 \mathrm{~g}$ daily, it is worth trying a larger dose but in this case the patient's condition should be monitored by blood film, haemoglobin, MCV, and reticulocyte count.

Sulphasalazine (SASP) has been found to be valuable for long-term maintenance treatment in order to prevent relapse in patients with ulcerative colitis. Misiewicz et al..$^{1}$ showed that SASP in a dose of $2 \mathrm{~g}$ daily sharply reduces the relapse rate at least for one year. Subsequently, a controlled trial in Oxford showed that the beneficial effect with SASP continues for longer periods and it was recommended that the drug should be continued indefinitely unless contraindicated by side-effects. ${ }^{2}$

Although SASP has been in use for more than 35 years, its optimum dose is unknown. The present study was designed to determine the therapeutic efficacy of various dosages of SASP as a form of maintenance treatment and at the same time to study the clinical, biochemical, and haematological sideeffects of these dosages. The aim was to arrive at the optimum dose for general use.

\section{Methods}

Patients with ulcerative colitis during remission were included in the study after giving their informed consent. Remission was defined as the absence of colitic symptoms and the absence of signs of inflammation on sigmoidoscopy and on histological examination of rectal biopsy specimens, as defined Received for publication 18 October 1979 by Truelove and Richards. ${ }^{3}$ There was a close correlation between the sigmoidoscopic appearances and the histological findings. However, three patients were thought to be free from inflammation by the sigmoidoscopist but the histology of the rectal biopsy was reported as showing mild inflammation. These three patients were excluded from the study.

One-hundred-and-seventy patients were included in the study, all but seven of whom were already on maintenance treatment with 2 g SASP daily, given in the form of plain tablets in divided doses. They were allotted at random to three different dosage groups of 1,2 , and $4 \mathrm{~g}$ SASP daily.

The patients in the three treatment groups were closely similar in respect of age and sex distribution, body weight, and extent of colonic involvement as judged radiologically.

The trial lasted for a period of six months. The patients were seen at the beginning, after three months and after six months, which was the end of the study. The patients and their general practitioners were instructed to contact us without delay and without any change in the medication if they felt that the colitic symptoms had recurred. All the patients were sigmoidoscoped and rectal biopsies were taken from each of them at the beginning of the trial and after six months. If clinical relapse occurred before six months, the patient was sig- 
moidoscoped and biopsied without delay and the trial was terminated as far as he was concerned, the relapse being treated in a standard way with oral prednisolone and topical corticosteroids in addition to the oral SASP. The histological examinations were performed by one pathologist (JP) who was unaware of the dose, the clinical state, and the sigmoidoscopic appearance.

Blood samples were drawn from these patients at the beginning, after three months, and after six months (or at the time of relapse if this occurred earlier). If there were intolerable clinical side-effects, the drug was stopped for a day or two and then started again with $1 \mathrm{~g}$ less than the trial dose. Additional blood samples were drawn before reducing the dose of SASP. The blood samples were used for the following measurements:

1 Serum concentrations of SASP and some of its metabolites: (a) SASP. (b) Free-SP. (c) Total-SP (free-SP and all its metabolites). (d) Total-5-ASA (free-5-ASA and AC-5-ASA). The acetylator status was determined from the ratio of free-SP to total-SP.

2 Some biochemical estimations: (a) Serum iron, folate, and $\mathrm{B}_{12}$. (b) Biochemical screening with Technicon 12 (serum $\mathrm{Ca}^{++}, \mathrm{PO}_{4} \equiv$, alkaline phosphatase, LDH, GOT, cholesterol, total protein, albumin and bilirubin; blood glucose, urea, uric acid and creatinine).

3 Glucose-6-phosphate-dehydrogenase (G6PD) in the erythrocytes.

4 Haematological estimations: (a) Leucocyte, thrombocyte, erythrocyte and reticulocyte counts. (b) Red cell indices. (c) Morphology of the erythrocytes and Heinz bodies. (d) Methaemoglobin. (e) ESR. (f) Direct Coombs' test.

All the above estimations were done without knowledge of the dose of the drug received by individual patients. Sulphasalazine and its metabolites were estimated in the serum on our behalf at the central laboratory of Pharmacia by the same standard methods as we have used ourselves in

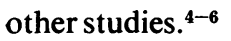

Estimations of leucocyte, thrombocyte, and erythrocyte counts; haemoglobin; red-cell indices; ESR; serum iron, folate, and $B_{12}$ and the biochemical screening were done through the routine clinical haematology and biochemistry laboratories of the Radcliffe Infirmary. The haematological studies were performed within 48 hours of the collection of blood. Leucocyte and erythrocyte counts and redcell indices were measured with a Coulter counter, Model. S. Platelet counts were made with a Technicon autocounter. The ESR was measured by Westergren method. Serum folate was estimated by microbiological assay; the bacteria employed (L. casei) were found to be unaffected by SASP, SP, and 5-ASA. Serum iron was estimated with a Technicon autoanalyser. Serum $B_{12}$ was estimated by radioimmunoassay. The other haematological studies were performed by one haematologist (DH). Reticulocytes were counted after staining with new methylene blue as described by Dacie and Lewis. ${ }^{7}$ Blood films were prepared on a clean glass slide without the use of anticoagulants at the time of venepuncture and these films were stained with Ames Herma-Tek Slide Stainer, using a modification of Wright's stain. Intravital staining for Heinz bodies was performed with $0.5 \%$ methyl violet in normal saline. Methaemoglobin estimation was done by a method based on that of Evelyn and Malloy. ${ }^{8}$ All the patients were screened for G6PDdeficiency by a modification of the method of Glock and McLean. ${ }^{9}$ All the patients were screened for erythrocyte autoantibody with the direct Coombs' test at the time of entry into the trial and at least once during the trial using Burroughs Wellcome Coombs reagent at two dilutions.

\section{Results}

CLINICAL EFFICACY

The clinical efficacy of the different dosages was judged by their ability to prevent relapses. Most of the relapses were associated with clinical symptoms of colitis but some patients remained free from symptoms, although sigmoidoscopy and histology of the rectal biopsy at the end of six months showed evidence of inflammation. In addition, a few patients were symptom-free and sigmoidoscopy showed only mild hyperaemia but the histology of the rectal mucosa showed definite evidence of inflammation.

In Table 1 and the Figure are shown the relapse rates in the three treatment groups. The overall! relapse rates in three treatment groups of 1,2 , and'

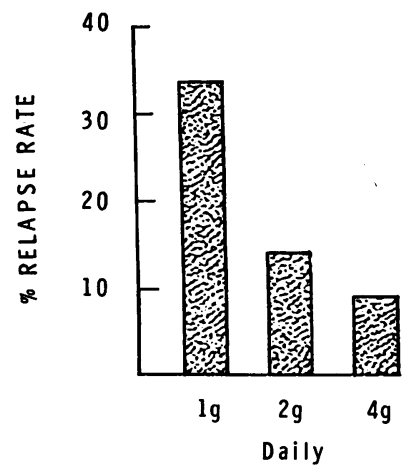

Figure Percentage relapse rates in the three different dosage groups. 
Table 1 Relapse rates in three dosage groups

\begin{tabular}{|c|c|c|c|c|c|c|}
\hline \multirow[b]{2}{*}{$\begin{array}{l}\text { Dose } \\
\text { (g/day) }\end{array}$} & \multirow[b]{2}{*}{$\begin{array}{l}\text { Patients } \\
\text { (total no.) }\end{array}$} & \multicolumn{4}{|c|}{ No. of patients who relapsed } & \multirow[b]{2}{*}{$\begin{array}{l}\text { Statistical } \\
\text { significance }\end{array}$} \\
\hline & & $\begin{array}{l}\text { Clinical }+ \\
\text { sigmoidoscopic } \\
\text { +histological }\end{array}$ & $\begin{array}{l}\text { Sigmoidoscopic } \\
\text { +histological } \\
\text { only }\end{array}$ & $\begin{array}{l}\text { Histological } \\
\text { only }\end{array}$ & Total & \\
\hline 1 & 57 & 13 & 3 & 3 & 19 & $x^{2}=12.297$ \\
\hline 2 & 57 & 5 & 1 & 2 & 8 & $\mathrm{n}=2$ \\
\hline 4 & 56 & 4 & 1 & 0 & 5 & $P<0.01$ \\
\hline
\end{tabular}

$4 \mathrm{~g}$ SASP daily were $33 \cdot 3,14 \cdot 0$, and $8 \cdot 9 \%$ respectively and these differences are statistically significant $(\mathrm{P}<0.01)$. If one considers only the clinical relapses, there is very little to choose between $2 \mathrm{~g}$ and $4 \mathrm{~g}$ as a daily dose of SASP. The clinical relapse rate with $1 \mathrm{~g}$ daily is much higher and, when compared with the combined results obtained with 2 and $4 \mathrm{~g}$ daily, the difference is significant ( $\chi^{2}$ with Yates' correction $=$ $6 \cdot 1, \mathrm{P}<0.02$ ). However, five of the 56 patients in the $4 \mathrm{~g}$ daily dosage group took that dose only for one week, as they could tolerate only 2 g SASP daily. One of these five patients had a clinical relapse. If these five patients are excluded from the $4 \mathrm{~g}$ daily dosage group and included in the $2 \mathrm{~g}$ daily dosage group, then the differences in the clinical relapse rates in the three different groups were statistically significant $\left(\chi^{2}=7 \cdot 768, P<0.05\right)$. In all the three groups, the clinical relapses were distributed almost uniformly over the whole period of six months. Out of the 32 patients who relapsed, 28 had distal colitis, two had extensive colitis, while two had universal colitis. Though a higher proportion of patients with distal colitis suffered from a relapse than those with extensive or universal colitis, the differences were not statistically significant. Of the 32 patients who relapsed, the acetylator status was known in 31 of them. Out of these 31 patients 18 were slow and 13 were fast acetylators. These figures are not appreciably different from the overall acetylator status of the total group of patients.
SERUM CONCENTRATIONS OF SASP AND ITS METABOLITES

Table 2 shows the serum concentrations of SASP, free-SP, total-SP, and total-5-ASA in patients maintained on different doses of SASP. There were marked interindividual variations in the serum concentration of SASP at a given dosage and even in the same patient from time to time. The mean serum concentration of SASP, however, showed a clear-cut dose relationship.

The serum concentration of total-SP showed less interindividual variation and most of the patients maintained a stable serum concentration of total-SP as long as the dose of SASP and the clinical state remained unaltered. Table 2 shows that the serum concentration of total-SP bore a linear relationship with the dose.

Table 2 Serum concentrations of SASP and its metabolites in patients on different dosages of $S A S P$

\begin{tabular}{|c|c|c|c|c|}
\hline & \multicolumn{4}{|c|}{ Daily dose of $S A S P(g)$} \\
\hline & 1 & 2 & 3 & 4 \\
\hline $\begin{array}{l}\text { Number of patients } \\
\text { SASP } \\
\text { Free-SP } \\
\text { Total-SP } \\
\text { Total-5-ASA }\end{array}$ & $\begin{array}{r}57 \\
6 \cdot 0 \pm 5 \cdot 7 \\
8 \cdot 2 \pm 3 \cdot 9 \\
13 \cdot 7 \pm 4 \cdot 8 \\
0 \cdot 7 \pm 0 \cdot 6\end{array}$ & $\begin{array}{r}57 \\
7 \cdot 7 \pm 7 \cdot 4 \\
14 \cdot 2 \pm 8 \cdot 9 \\
23 \cdot 4 \pm 11 \cdot 8 \\
1 \cdot 1 \pm 1 \cdot 2\end{array}$ & $\begin{array}{l}10 \\
10 \cdot 8 \pm 4 \cdot 0 \\
29 \cdot 1 \pm 12 \cdot 2 \\
40 \cdot 6 \pm 7 \cdot 0 \\
1.5 \pm 0.8\end{array}$ & $\begin{array}{l}56 \\
19 \cdot 3 \pm 16 \cdot 8 \\
30.9 \pm 17 \cdot 7 \\
49 \cdot 6 \pm 20 \cdot 3 \\
1.6 \pm 1.0\end{array}$ \\
\hline
\end{tabular}

The serum concentrations are expressed as $\mu \mathrm{g} / \mathrm{ml}$ and the values shown are the mean and standard deviation for each treatment group. The small group of $\mathbf{1 0}$ patients on $\mathbf{3} \mathrm{g}$ daily was switched from the $\mathbf{4 g}$ group because of unpleasant symptoms.

Table 3 Serum concentration of SASP and its metabolites in fast and slow acetylators in patients on different doses of SASP

\begin{tabular}{|c|c|c|c|c|c|c|c|c|c|}
\hline & \multicolumn{9}{|c|}{ Dose of SASP daily } \\
\hline & \multicolumn{3}{|l|}{$I g$} & \multicolumn{3}{|l|}{$2 g$} & \multicolumn{3}{|l|}{$4 g$} \\
\hline & $\begin{array}{l}\text { Fast } \\
\text { acetylator } \\
n=19\end{array}$ & $\begin{array}{l}\text { Slow } \\
\text { acetylator } \\
n=33\end{array}$ & $t$ test & $\begin{array}{l}\text { Fast } \\
\text { acetylator } \\
n=23\end{array}$ & $\begin{array}{l}\text { Slow } \\
\text { acetylator } \\
n=33\end{array}$ & $t$ test & $\begin{array}{l}\text { Fast } \\
\text { acetylator } \\
n=21\end{array}$ & $\begin{array}{l}\text { Slow } \\
\text { acetylator } \\
n=35\end{array}$ & t test \\
\hline $\begin{array}{l}\text { SASP } \\
\text { Free-SP }\end{array}$ & $\begin{array}{l}4 \cdot 5 \pm 2 \cdot 7 \\
4 \cdot 7 \pm 1 \cdot 4\end{array}$ & $\begin{array}{r}7 \cdot 4 \pm 6 \cdot 9 \\
11 \cdot 0 \pm 2 \cdot 3\end{array}$ & $\begin{array}{l}t=1.7 \mathrm{NS} \\
t=10.1 \\
\mathrm{P}<0.0001\end{array}$ & $\begin{array}{r}10.0 \pm 10.9 \\
8.6 \pm 3.6\end{array}$ & $\begin{array}{r}6 \cdot 4 \pm 2.6 \\
18 \cdot 5 \pm 9 \cdot 0\end{array}$ & $\begin{array}{l}t=1.8 \mathrm{NS} \\
t=4.7 \\
\mathrm{P}<0.001\end{array}$ & $\begin{array}{l}16 \cdot 8 \pm 17 \cdot 2 \\
14 \cdot 9 \pm 8 \cdot 5\end{array}$ & $\begin{array}{l}21 \cdot 1 \pm 16 \cdot 9 \\
41 \cdot 2 \pm 14 \cdot 1\end{array}$ & $\begin{array}{l}t=0.9 \mathrm{NS} \\
t=7.1 \\
\mathrm{P}<0.0001\end{array}$ \\
\hline Total-SP & $12 \cdot 1 \pm 3 \cdot 4$ & $15 \cdot 9 \pm 3 \cdot 4$ & $\begin{array}{l}t=3.7 \\
\mathrm{P}<0.001\end{array}$ & $19.4 \pm 7.6$ & $27 \cdot 0 \pm 12 \cdot 7$ & $\begin{array}{l}t=2.5 \\
\mathrm{P}<0.02\end{array}$ & $35 \cdot 7 \pm 17 \cdot 3$ & $57.9 \pm 18.0$ & $\begin{array}{l}t=4.3 \\
\mathrm{P}<0.001\end{array}$ \\
\hline Total-5-ASA & $0 \cdot 7 \pm 0 \cdot 3$ & $0.7 \pm 0.7$ & $t=0.5 \mathrm{NS}$ & $1 \cdot 2 \pm 1 \cdot 8$ & $1 \cdot 1 \pm 0.8$ & $t=0.5 \mathrm{NS}$ & $1 \cdot 3 \pm 0 \cdot 7$ & $1.9 \pm 1.2$ & $t=1.7 \mathrm{NS}$ \\
\hline
\end{tabular}

The serum concentrations are expressed as $\mu \mathrm{g} / \mathrm{ml}$ and the values shown are the mean and the standard deviation. 
The serum concentration of total-5-ASA was usually very low at all three dosages but occasionally a patient was found to have a serum concentration of over $6 \mu \mathrm{g} / \mathrm{ml}$. This was possibly due to the incidental ingestion of other salicylates, such as aspirin, which are also measured by the present method for estimating 5-ASA. ${ }^{2} 10$ In spite of these discrepant observations, the serum concentration of total-5-ASA showed a reasonable relationship with the dose of SASP.

\section{ACETYLATOR PHENOTYPE}

The acetylator phenotype was determined for all the patients except for six in whom the serum concentrations of SP were too low to allow for an accurate determination of the phenotype. The method used was that of Evans. ${ }^{11}$ There were 63 fast acetylators and 101 slow acetylators; these proportions are similar to those found by Evans ${ }^{11}$ for the normal British population. The three dosage groups were closely similar in respect of the proportions of fast and slow acetylators.

Table 3 shows the serum concentration of SASP and its metabolites in the fast and slow acetylators of the different dosage groups. The serum concentrations of SASP and total 5-ASA were similar in fast and slow acetylators. By contrast, the mean serum concentration of total-SP was significantly higher in the slow acetylators than in the fast acetylators in all the three dosage groups. The serum concentrations of free-SP were much higher in the slow acetylators than in the fast acetylators.

\section{SYMPTOMATIC SIDE-EFFECTS}

It has already been mentioned that 163 out of the 170 patients had already been taking 2 g SASP daily before entry into the present trial. It is therefore not surprising that the symptomatic side-effects were restricted to the group of patients in whom the dose was increased to $4 \mathrm{~g}$ daily. Twenty-one out of the total number of 56 patients in this group experienced symptomatic side-effects, 12 of them suffering from more than one. Most of these sideeffects occurred within four days of increasing the dose and they were all manifest within one week. Tables 4 and 5 set out these side-effects and show their relation to the circulating concentrations of SASP and its metabolites.

There was no appreciable difference in the serum concentration of SASP between the group of patients who suffered from symptomatic side-effects and the group of patients who were able to continue taking 4 g SASP without such side-effects. By contrast, the serum concentration of total-SP was

Table 4 Serum concentration of SASP and its metabolites, and acetylator phenotypes of patients, ingesting $4 \mathrm{~g}$ SASP daily, with or without clinical side-effects

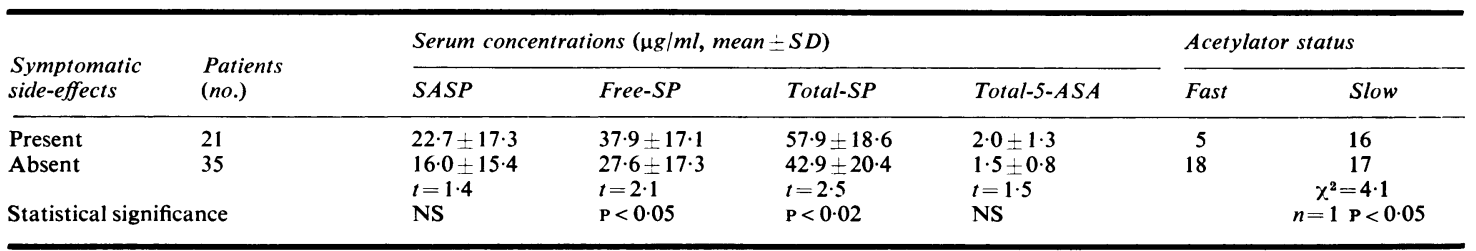

Table 5 Symptomatic side-effects* in patients ingesting $4 \mathrm{~g}$ SASP daily and their relation to serum concentration of SASP and its metabolites and to acetylator status

\begin{tabular}{|c|c|c|c|c|c|c|c|}
\hline \multirow[t]{2}{*}{ Side-effects } & \multirow[t]{2}{*}{ No. } & \multicolumn{4}{|c|}{ Serum concentrations $(\mu \mathrm{g} / \mathrm{ml})($ mean $\pm S D)$} & \multicolumn{2}{|c|}{ Acetylator status } \\
\hline & & $S A S P$ & Free-SP & Total-SP & Total-5-ASA & Fast & Slow \\
\hline Malaise & 5 & $29 \cdot 4 \pm 19.9$ & $45 \cdot 5 \pm 8.9$ & $68 \cdot 0 \pm 13 \cdot 8$ & $1.8 \div 0 \cdot 5$ & 0 & 5 \\
\hline Headache & 4 & $9 \cdot 0 \pm 3.4$ & $48 \cdot 1=18 \cdot 4$ & $67 \cdot 2 \pm 19 \cdot 4$ & $3 \cdot 1 \pm 2 \cdot 7$ & 0 & 4 \\
\hline Myalgia & 2 & $36 \cdot 5$ & $49 \cdot 7$ & $76 \cdot 9$ & $1 \cdot 1$ & 0 & 2 \\
\hline Diarrhoea & 2 & $17 \cdot 5$ & $28 \cdot 9$ & $59 \cdot 0$ & $1 \cdot 8$ & 1 & 1 \\
\hline Anal soreness & 2 & $10 \cdot 6$ & $30 \cdot 0$ & $53 \cdot 4$ & $2 \cdot 0$ & 1 & 1 \\
\hline Anal mucous discharge & 1 & $33 \cdot 2$ & $50 \cdot 1$ & $62 \cdot 6$ & 1.9 & 0 & 1 \\
\hline Flatulence & 2 & $20 \cdot 8$ & $62 \cdot 1$ & $75 \cdot 0$ & $3 \cdot 1$ & 1 & 1 \\
\hline Dysuria & 3 & $17 \cdot 1$ & $39 \cdot 6$ & $67 \cdot 0$ & 1.9 & 1 & 2 \\
\hline Anorexia & 2 & $15 \cdot 1$ & 33.0 & $53 \cdot 2$ & 1.9 & 0 & 2 \\
\hline Indigestion & 1 & $13 \cdot 7$ & $44 \cdot 5$ & $64 \cdot 2$ & $2 \cdot 0$ & 0 & 1 \\
\hline Insomnia & 1 & 21.0 & $41 \cdot 1$ & $67 \cdot 8$ & $2 \cdot 8$ & 0 & 1 \\
\hline Dizziness & 2 & $12 \cdot 5$ & $26 \cdot 2$ & $47 \cdot 6$ & 1.0 & 1 & 1 \\
\hline
\end{tabular}


significantly higher in the patients who developed symptomatic side-effects than in those who did not suffer from any such side-effects. The serum concentration of total-5-ASA was also higher in the symptomatic group but the difference was not significant (Table 5). The serum concentration of total-5-ASA was, however, very low and hence the 5-ASA is unlikely to be the cause of any of these side-effects. Both SP and 5-ASA are produced in the colon from SASP and therefore a positive correlation between their serum concentrations is to be expected and this was actually the case $(r=0.632, \mathrm{P}<0.001)$. There was no correlation between the serum concentration of SASP and the serum concentration of either total-SP or total-5-ASA. Hence it is probable that most of the clinical side-effects were due to circulating SP. It is, however, worth mentioning that, although most of the side-effects occurred in patients with a high circulating concentration of total-SP, some patients with a high serum concentration of total-SP were completely free from symptoms.

ACETYLATOR PHENOTYPES AND SYMPTOMATIC SIDE-EFFECTS

In the group of patients allotted to $4 \mathrm{~g}$ sulphasalazine daily, the acetylator phenotype was known for all the 56 patients. Table 4 shows that the symptomatic side-effects were significantly more common among the slow acetylators. Table 5, which sets out the individual side-effects, demonstrates that the common effects of nausea, malaise, and headache were almost completely confined to the slow acetylators.

\section{PRACTICAL MEASURES ADOPTED WITH PATIENTS EXPERIENCING SYMPTOMATIC SIDE-EFFECTS}

In order to avoid the effect of suggestion in inducing symptoms, the patients were not specifically questioned with regard to the occurrence of symptomatic side-effects but were simply instructed to contact us without delay in the event of any new symptoms developing. They were then seen within a day or two and, assuming that the symptoms appeared to be side-effects of the SASP, they were asked whether they regarded the new symptoms as intolerable. If so, a sample of venous blood was taken and the medication was stopped for one day and then started again in a dosage of $3 \mathrm{~g}$ SASP daily. In the event of further intolerance, the same procedure was followed and the dose was further reduced to $2 \mathrm{~g}$ daily. Of the 21 patients who experienced symptomatic side-effects, eight were able to continue with the full dose of $\mathbf{4} \mathrm{g}$ daily as their side-effects were mild. In eight patients, the dose had to be reduced to $3 \mathrm{~g}$ daily, while in the remaining five patients it was necessary to reduce the dose further to $2 \mathrm{~g}$ daily. None of the patients needed to lower his dose below $2 \mathrm{~g}$ daily. The group of 13 patients who developed intolerable clinical side-effects had a mean serum concentration of total-SP of $60.7 \mu \mathrm{g} / \mathrm{ml}$ before reducing their dose of SASP, while the group of eight patients who were able to continue $4 \mathrm{~g}$ SASP daily in spite of mild clinical symptoms had a mean serum concentration of total-SP of $51.6 \mu \mathrm{g} / \mathrm{ml}$. This difference, however, is not statistically significant.

\section{BIOCHEMICAL AND HAEMATOLOGICAL}

\section{EFFECTS}

No drug-related abnormalities appeared in the serum biochemical measurements. The serum vitamin $B_{12}$ and folate levels likewise remained normal in all the patients. All but one of the patients had erythrocyte G6PD levels which were normal; the one exception was a British subject of Caucasian stock who showed only a mild depression of the enzyme and no evidence of haemolysis.

The direct Coombs' test remained negative in all the patients. There was no appreciable difference in the three dosage groups of patients in respect of the leucocyte and thrombocyte counts and the ESR. However, some minor haematological abnormalities could be detected. In Table 6 are shown the haematological abnormalities in the three groups of patients. In the present study, anaemia has been defined as a haemoglobin below $13.5 \mathrm{~g} / \mathrm{dl}$ for men and $11.5 \mathrm{~g} / \mathrm{dl}$ for women. Some of these patients suffered from a relapse of the ulcerative colitis during the study but, if they are excluded, the results remain essentially the same.

Iron deficiency with or without anaemia and normochromic normocytic anaemia were seen in some patients but these abnormalities were randomly

Table 6 Haematological abnormalities in patients with ulcerative colitis (including those during relapse) on different doses of $S A S P$

\begin{tabular}{|c|c|c|c|c|}
\hline \multirow[b]{3}{*}{ Number of patients } & \multicolumn{3}{|c|}{ Daily dose of $S A S P(g)$} & \multirow{3}{*}{$\begin{array}{l}\text { Significance of } \\
\text { difference }\end{array}$} \\
\hline & \multirow{2}{*}{$\frac{1}{57}$} & \multirow[b]{2}{*}{62} & \multirow{2}{*}{$\frac{4 \text { or } 3}{51}$} & \\
\hline & & & & \\
\hline $\begin{array}{l}\text { Iron deficiency } \\
\text { Normochromic }\end{array}$ & $9(4)$ & $10(6)$ & $3(2)$ & NS \\
\hline $\begin{array}{l}\text { normocytic anaemia } \\
\text { Macrocytosis }\end{array}$ & 9 & 5 & 9 & NS \\
\hline$(\mathrm{MCV}>100 \mathrm{f} 1)$ & $\mathbf{0}$ & $7(1)$ & $10(5)$ & $\chi^{2}=11.6, P<0.01$ \\
\hline Reticulocytosis ( $>2 \%$ ) & $\mathbf{0}$ & $3(0)$ & $4(1)$ & NS \\
\hline $\begin{array}{l}\text { Heinz bodies } \\
\text { Methaemoglobinaemia }\end{array}$ & $\mathbf{0}$ & $3(0)$ & $5(1)$ & NS \\
\hline $\begin{array}{l}(>1.5 \%) \\
\text { Crenated RBC } \\
\text { No abnormality }\end{array}$ & $\begin{array}{l}12 \\
16 \\
26\end{array}$ & $\begin{array}{l}24 \\
27 \\
18\end{array}$ & $\begin{array}{r}29 \\
36 \\
7\end{array}$ & $\begin{array}{l}\chi^{2}=14.6, P<0.001 \\
\chi^{2}=19.9, P<0.001 \\
\chi^{2}=13.1, P<0.01\end{array}$ \\
\hline
\end{tabular}

Numbers in parentheses refer to patients who were anaemic. 
Table 7 Haematological ahnormalities and their relation to serum concentration of total-SP in patients with ulcerative colitis on different doses of SASP

\begin{tabular}{|c|c|c|c|c|c|c|c|c|c|}
\hline \multirow{4}{*}{ No. of patients } & \multicolumn{9}{|c|}{ Daily dose of SASP } \\
\hline & \multicolumn{3}{|l|}{$1 \mathrm{~g}$} & \multicolumn{3}{|l|}{$2 g$} & \multicolumn{3}{|l|}{3 or $4 g$} \\
\hline & \multicolumn{3}{|l|}{57} & \multicolumn{3}{|l|}{62} & \multicolumn{3}{|l|}{51} \\
\hline & Present & Absent & t test & Present & Absent & $t$ test & Present & Absent & $t$ test \\
\hline Crenated RBC & $14 \cdot 1 \pm 4 \cdot 7$ & $13 \cdot 4 \pm 5 \cdot 0$ & NS & $30 \cdot 4 \pm 11 \cdot 7$ & $19 \cdot 4 \pm 9 \cdot 2$ & $\begin{array}{l}t=4.2 \\
\mathrm{P}<0.001\end{array}$ & $51 \cdot 8 \pm 18 \cdot 0$ & $35 \cdot 5-22 \cdot 3$ & $\begin{array}{l}t=2.7 \\
\mathrm{P}<0.02\end{array}$ \\
\hline $\begin{array}{l}\text { Methaemoglobinaemia } \\
(>1.6 \% \\
\text { methaemoglobin) } \\
\text { Macrocytosis }\end{array}$ & $13 \cdot 3 \pm 4 \cdot 4$ & $13 \cdot 6 \pm 5 \cdot 0$ & NS & $24 \cdot 9 \pm 12 \cdot 3$ & $21 \cdot 4 \pm 10 \cdot 1$ & NS & $48 \cdot 6 \pm 21 \cdot 7$ & $44 \cdot 1 \pm 20 \cdot 3$ & NS \\
\hline$(\mathrm{MCV}>100 \mathrm{f} 1)$ & - & - & - & $25 \cdot 6 \pm 8 \cdot 8$ & $22 \cdot 4 \pm 11.9$ & NS & $62 \cdot 1 \pm 12 \cdot 3$ & $45 \cdot 7 \pm 21 \cdot 2$ & $\begin{array}{l}t=2.3 \\
\mathrm{P}<0.05\end{array}$ \\
\hline $\begin{array}{l}\text { Reticulocytosis } \\
\quad(>2 \% \text { reticulocytes })\end{array}$ & - & - & - & $26 \cdot 8 \pm 13 \cdot 3$ & $23 \cdot 1 \pm 11 \cdot 8$ & NS & $70 \cdot 0 \pm 12 \cdot 4$ & $44 \cdot 5 \pm 19 \cdot 9$ & $\begin{array}{l}t=2.5 \\
\mathrm{P}<0.02\end{array}$ \\
\hline Heinz bodies & - & - & - & $37 \cdot 4 \pm 12.9$ & $22 \cdot 6 \pm 11 \cdot 2$ & $\begin{array}{l}t=2.5 \\
\mathrm{P}<0.02\end{array}$ & $60 \cdot 9 \pm 9 \cdot 5$ & $44 \cdot 5 \pm 20 \cdot 4$ & NS \\
\hline
\end{tabular}

Serum concentrations are expressed as $\mu \mathrm{g} / \mathrm{ml}$ and the values shown are the mean and the standard deviation.

distributed in the three dosage groups. Hence it is unlikely that SASP had caused them. The normochromic normocytic anaemia was probably a direct result of the ulcerative colitis, as it is a common manifestation of many chronic diseases. Iron deficiency was probably due to a marked depletion of the iron stores as a result of previous attacks of colitis. Some patients apparently felt well in spite of a low serum iron. The dose-related haematological abnormalities seen in this study are well-recognised features of drug-induced erythrocyte damage. None of the patients, however, developed a frank haemolytic anaemia.

Some of the haematological abnormalities were dose-related, as shown in Table 6. With the exception of methaemoglobinaemia, these dose-related abnormalities correlated with the circulating levels of total-SP, especially in the high dosage group (Table 7). Further analysis of the data has shown that these abnormalities are associated with the free-SP component of the total-SP and thus these complications are more likely to occur in the slow acetylators, a feature which is described in detail in another article dealing especially with the acetylator phenotype in relation to SASP therapy (unpublished observations). By contrast, the methaemoglobinaemia has been found to correlate with the circulating levels of acetylated SP and hence is specially prone to occur in fast acetylators, especially on a high dosage of SASP.

\section{Discussion}

The present study has shown that the clinical efficacy of SASP, as judged by its ability to maintain remission in patients with ulcerative colitis, improves with increasing dosage. Although a maintenance dose of $1 \mathrm{~g}$ SASP daily is less than ideal, this dose is almost certainly better than no SASP at all. It is not ideal to compare the results of one therapeutic trial with those of another, but both Misiewicz et al. ${ }^{1}$ and Dissanayake and Truelove $^{2}$ found that more than $50 \%$ of their patients with ulcerative colitis relapsed within six months while being maintained on dummy tablets, a figure much higher than the relapse rate observed in the $1 \mathrm{~g}$ dosage group in the present study. Moreover, in these two previous studies, the relapse rate in patients maintained on 2 g SASP daily was about $12 \%$, which is closely similar to the figure of $14 \%$ observed in the present study among the group of patients on this dosage.

The situation becomes more complicated when the maintenance dose is increased from $2 \mathrm{~g}$ daily to $4 \mathrm{~g}$ daily. Firstly, the clinical efficacy is improved, although the difference is not big. Secondly, an appreciable number of patients find that $4 \mathrm{~g}$ SASP daily is unacceptable because of the symptomatic side-effects.

The side-effects of SASP can be divided into two main groups: (1) side-effects which are not related to the dose of the drug and hence are largely unpredictable; and (2) dose-related side-effects, which are thus predictable to a large extent.

The first group of side-effects consists mainly of skin rashes, bone-marrow depression, non-oxidative haemolysis-that is, autoimmune-and lung changes. None of these side-effects was observed during the present study. It seems that, if non-dose-related side-effects do not occur during the initiation of the therapy, they are unlikely to occur later. 
Quantitative information on the incidence of adverse effects at different dosages of SASP is scanty. Schröder and Evans ${ }^{12}$ put 27 healthy volunteers on $4 \mathrm{~g}$ SASP daily for five days. About $88 \%$ of the subjects experienced some adverse symptoms and about $63 \%$ of them stopped taking the drug before five days because they found these symptoms intolerable. The authors rightly pointed out that the side-effects in healthy volunteers may not reflect the incidence in patients with ulcerative colitis. Das et al..$^{13}$ found that $21 \%$ of patients with ulcerative colitis or Crohn's disease suffered from adverse effects (including some haematological abnormalities) while on SASP therapy. Their patients were taking 1.5 to $8 \mathrm{~g}$ SASP daily. The authors noted that the incidence of side-effects increased with the dose.

Studies by other workers have shown that the incidence of side-effects in patients on $2 \mathrm{~g} \mathrm{SASP}$ daily is not high. Misiewicz et al. ${ }^{1}$ found that $8.8 \%$ of their patients (total number of patients in the study was 34) could not tolerate $2 \mathrm{~g}$ SASP daily. The incidence of clinical side-effects seems to increase sharply when the dose of SASP is increased from 2 to $4 \mathrm{~g}$ daily, as $37.5 \%$ of our patients on $4 \mathrm{~g}$ daily experienced some adverse symptoms. These symptoms were unacceptable to $23.2 \%$ of the patients and the dose of SASP had to be reduced. The incidence of side-effects is very high if the dose is increased to more than $4 \mathrm{~g}$ daily. ${ }^{14}$

The common symptoms of intolerance found in the present study were nausea, headache, and malaise, which have been found to be common side-effects of SASP therapy by many other workers., 12-23

These symptomatic side-effects showed a positive correlation with the serum concentration of total-SP. They were experienced within a week when the dose of SASP was increased from 2 to $4 \mathrm{~g}$ daily. It is known that, after regular ingestion of a given dose of SASP, the serum concentration of SP reaches a steady state within three days. Nausea, headache, and malaise are common symptoms in patients on sulphonamide therapy. ${ }^{11} 24$

The symptomatic side-effects occurred more frequently in the slow acetylators than in the fast acetylators. This is to be expected because slow acetylators tend to have high serum concentrations of total-SP. However, the acetylator status is not the only factor regulating the serum concentration of total-SP at a given dosage of SASP, because hydroxylation and glucuronidation may also be important. ${ }^{12}$ It is also possible that different metabolites of SP differ in their capacity to produce side-effects at a given serum concentration. That the side-effects correlate with the serum concentration of total-SP and acetylator status has also been observed by other workers. ${ }^{1213}$ The acetylator phenotype is known to influence the side-effects due to other drugs that are metabolised by acetylation..$^{25-28}$

Haematological abnormalities which were doserelated were restricted to erythrocytes. There was no case of leucopenia, bone-marrow depression, or autoimmune haemolytic anaemia. It is known that these side-effects develop during the initial few weeks after the beginning of therapy ${ }^{29}$ and as the patients participating in the present study had been taking SASP for some time before their inclusion in the study it is not surprising that these particular sideeffects did not occur.

Although there was no case of frank haemolytic anaemia, there was other evidence of drug-induced red cell injury, in the form of crenated erythrocytes, macrocytosis, increased reticulocyte counts, and the presence of Heinz bodies. Indeed, the difference between mild and severe haemolysis is quantitative rather than qualitative. These abnormalities were related to the dose of SASP. Crenated erythrocytes were seen in 28,44 , and $71 \%$ of the patients at 1,2 , and $4 \mathrm{~g}$ dosage of SASP respestively. Pounder and colleagues $^{30}$ observed crenated red cells in over $30 \%$ and $80 \%$ of patients at 2 and $4 \mathrm{~g}$ dosage of SASP respectively. The numbers of patients in their study were small, but these figures are comparable with the findings in the present study. However, they did not find crenated erythrocytes in patients taking $1.5 \mathrm{~g}$ or less of SASP daily, but very few of their patients were taking such a small dose. The authors thought that ' $1.5 \mathrm{~g} /$ day sulphasalazine is not likely to cause red cell damage.' However, no patient in the $1 \mathrm{~g}$ dosage group developed macrocytosis, reticulocytosis, or Heinz bodies. Macrocytosis is possibly due to a younger red cell population entering the circulation as a result of minimal haemolysis. It has been reported that SASP can interfere with folate absorption ${ }^{31}$, but chronic haemolysis may itself induce a relative folate deficiency. None of the patients taking part in the present study, however, developed folate deficiency. Only six of the patients were actually anaemic in a form which could be interpreted as drug-induced anaemia; five of them were in the $4 \mathrm{~g}$ dosage group, while only one was in the $2 \mathrm{~g}$ dosage group and there was none in the $1 \mathrm{~g}$ dosage group. In the absence of an abnormal haemoglobin, Heinz bodies are a definite indication of drug-induced injury to the erythrocytes. ${ }^{7}$ There was no reason to suspect the presence of an abnormal haemoglobin in any of the patients participating in the present study. Moreover, the incidence of Heinz bodies was dose-related. Heinz body anaemia has long been recognised as a complication of sulphasalazine therepy. ${ }^{13}{ }^{32-34}$ With the exception of methaemoglobinaemia, the doserelated erythrocyte abnormalities occurred more 
frequently in patients with high serum concentrations of total-SP and in the slow acetylators. The acetylator status and the serum concentration of total-SP are, however, related to one another. As in the case of symptomatic side-effects, there were variations in the individual susceptibility. Sulphonamides, especially sulphapyridine, are known to damage erythrocytes by oxidation ${ }^{24}$ and the damage tends to be severe in G6PD-deficient subjects. ${ }^{35}$ Glucose-6-phosphate dehydrogenase deficiency is genetically determined and is chiefly found in negroes and in some Mediterranean races. All the subjects in the present study were native British of Caucasian stock and in only one of them was the G6PD level below the lower limit of normal, and then only slightly so. Moreover, this particular patient did not develop Heinz bodies. The present study confirms the finding of Gabor $^{36}$ that sulphasalazine-induced erythrocyte damage can occur even in the presence of a normal G6PD level.

Mild methaemoglobinaemia was common in the patients participating in the present study and it was related to the dose of SASP. It occurred chiefly in patients with high serum concentrations of acetylated SP and hence was prone to occur among the fast acetylators, especially at the high dosage levels of SASP.

\section{Conclusions}

The present study suggests that, for general use, a daily dose of $2 \mathrm{~g} \mathrm{SASP}$ is satisfactory for the maintenance treatment of ulcerative colitis. A larger dose of $4 \mathrm{~g}$ daily gives a slightly lower relapse rate but at the price of a considerable increase in the side-effects of therapy. However, if a patient does not do well on a dose of $2 \mathrm{~g}$ daily, it is worth trying a larger dose but, if so, the effects should be monitored by blood film, haemoglobin, MCV, and reticulocyte count. If there is clinical intolerance to these larger doses, the drug should be stopped for a day or two and then restarted at a lower level.

Some patients are unable to tolerate even $2 \mathrm{~g}$ SASP daily. In such circumstances, a smaller dose, such as $1 \mathrm{~g}$ daily, is worth using. Although the relapse rate is decidedly higher than with $2 \mathrm{~g}$ daily, it is still much lower than that experienced by patients on no form of maintenance therapy.

\section{References}

${ }^{1}$ Misiewicz JJ, Lennard-Jones JE, Connell AM, Baron JH, Jones F Avery. Controlled trial of sulphasalazine in maintenance therapy for ulcerative colitis. Lancet 1965 ; 1: 185-8.

${ }^{2}$ Dissanayake AS, Truelove SC. A controlled therapeutic trial of long-term maintenance treatment of ulcerative colitis with sulphasalazine (Salazopyrin). Gut 1973; 14: 923-6.

${ }^{3}$ Truelove SC, Richards WCD. Biopsy studies in ulcerative colitis. Br Med J 1956; 1 : 1315-8.

${ }^{4}$ Hansson K-A. Determination of free and acetylated 5aminosalicylic acid in serum and urine after administration of salicylazosulphapyridine. Acta Pharm Suec 1973; 10: $153-5$.

${ }^{5}$ Hansson K-A, Sandberg M. Determination of sulphapyridine and its metabolites in biological materials after administration of salicylazosulphapyridine. Acta Pharm Suec 1973; 10: 87-92.

${ }^{6}$ Sandberg M, Hansson K-A. Determination of salicylazosulphapyridine in biological materials. Acta Pharm Suec 1973; 10: 107-10.

'Dacie JV, Lewis SM. Practical haematology. 5th ed. Edinburgh: Churchill Livingstone, 1975.

${ }^{8}$ Evelyn KA, Malloy HT. Microdetermination of oxyhemoglobin, methemoglobin, and sulphemoglobin in a single sample of blood. J Biol Chem 1938; 126: 655-62.

${ }^{9}$ Glock GE, McLean P. Further studies on the properties and assay of glucose-6-phosphate dehydrogenase and 6-phosphogluconate dehydrogenase of rat liver. Biochem $J$ 1953; 55: 400-8.

${ }^{10}$ Forrest JAH, Park J, Heading R C. Salicylate ingestion in patients attending a gastrointestinal clinic. Gut 1977; 18: A422. (abstract).

${ }^{11}$ Evans, DAP. An improved and simplified method of detecting the acetylator phenotype. J Med Genet 1969; 6: 405-7.

${ }^{12}$ Schröder H, Evans DAP. Acetylator phenotype and adverse effects of sulphasalazine in healthy subjects. Gut 1972; 13: 278-84.

${ }^{13}$ Das KM, Eastwood MA, McManus JPA, Sircus W. The metabolism of salicylazosulphapyridine in ulcerative colitis. I. The relationship between metabolites and the response to treatment in in-patients. II. The relationship between metabolites and the progress of the disease studied in out-patients. Gut 1973; 14: $631-41$.

${ }^{14}$ Truelove SC, Watkinson G, Draper G. Comparison of corticosteroid and sulphasalazine therapy in ulcerative colitis. Br Med J 1962; 2: 1708-11.

${ }^{15}$ Svartz N. Salazopyrin, a new sulfanilamide preparation. A. Therapeutic results in rheumatic polyarthitis. B. Therapeutic results in ulcerative colitis. C. Toxic manifestations in treatment with sulfanilamide preparations. Acta Med Scand 1942; 110: 577-98.

${ }^{16}$ Lagercrantz R. Ulcerative colitis in children. Acta Paediatr (Uppsala) 1949; Suppl. No. 75: 89-151.

${ }^{17}$ Morrison LM. Results of treatment of ulcerative colitis with salicylazosulfapyridine. Gastroenterology 1952; 21: 133-8.

${ }^{18}$ Moertel CG, Bargen JA. A critical analysis of the use of salicylazosulfapyridine in chronic ulcerative colitis. Ann Intern Med 1959; 51 : 879-89.

${ }^{19}$ Lennard-Jones JE, Longmore AJ, Newell AC, Wilson CWE, Jones F Avery. An assessment of prednisolone, salazopyrin and topical hydrocortisone hemisuccinate used as out-patient treatment for ulcerative colitis. Gut $1960 ; 1$ : 217-22. 
${ }^{20}$ Watkinson G. Medical management of ulcerative colitis. Br Med J 1961; 1 : 147-51.

${ }^{21}$ Baron JH, Connell AM, Lennard-Jones JE, Jones F Avery. Sulphasalazine and salicylazosulphadimidine in ulcerative colitis. Lancet 1962; 1: 1094-96.

${ }^{22}$ Dick AP, Grayson MJ, Carpenter RG, Petrie A. Controlled trial of sulphasalazine in the treatment of ulcerative colitis. Gut 1964; 5: 437-42.

${ }^{23}$ Collins JR. Adverse reactions to salicylazosulfapyridine (azulfidine) in the treatment of ulcerative colitis. Sth Med J 1968; 61 : 354-8.

${ }^{24}$ Hawking F, Lawrence JS. The sulphonamides. London: Lewis, 1950.

${ }^{25}$ Hughes HB, Biehl JP, Jones AP, Schmidt LH. Metabolism of isoniazid in man as related to the occurrence of peripheral neuritis. Am Rev Tuberc 1954; 70: 266-73.

${ }^{26}$ Devadatta S, Gangadharam PRJ, Andrews RH, et al. Peripheral neuritis due to isoniazid. Bull WHO 1960 ; 23: 587-98.

${ }^{27}$ Evans D.AP, Davison K, Pratt RTC. The influence of acetylator phenotype on the effects of treating depression with phenelzine. Clin Pharmacol Ther 1965; 6: 430-5.

${ }^{28}$ Perry HM, Jr., Sakamoto A, Tan EM. Relationship of acetylating enzyme to hydralazine toxicity. $J$ Lab Clin Med 1967; 70: 1020-21. (abstract)

${ }^{29}$ Swaim WR, Jamshidi, K, Arlander T, Garcia MC,
Windschidtl HW. Azulfidine agranulocytosis with bone marrow megakaryocytosis, histiocytosis and plasmacytosis. Minn Med 1972; 55: 545-8.

${ }^{30}$ Pounder RA, Craven ER, Henthorn JS, Bannatyne JM. Red cell abnormalities associated with sulphasalazine maintenance therapy for ulcerative colitis. Gut 1975; 16: 181-5.

${ }^{31}$ Franklin JL, Rosenberg IH. Impaired folic acid absorption in inflammatory bowel disease: effects of salicylazosulfapyridine (Azulfidine). Gastroenterology 1973; 64: 517-25.

${ }^{32}$ Spriggs AI, Smith RS, Griffith H, Truelove SC. Heinzbody anaemia due to salicylazosulphapyridine. Lancet 1958; 1 : 1039-42.

${ }^{33}$ Böttiger LE, Engstedt L, Lagercrantz, R, Nyberg, A. The occurrence of Heinz bodies during azulfidine treatment of ulcerative colitis. Gastroenterol Basel 1963 100: $33-41$.

${ }^{34}$ Miller B, Sandrock K, Goebel KM et al. Untersuchungen zum Mechanismus der Hämiglobinbildung durch Salicylazosulfapyridin (Azulfidine). Verh Dtsch Ges Inn Med 1971; 78: 698-700.

${ }^{35}$ Harris JW, Kellermeyer RW. The red cell. Cambridge, Mass: Harvard University Press, 1970.

${ }^{36}$ Gabor P. Hemolytic anemia as adverse reaction to salicylazosulfapyridine. (Letter) $N$ Engl J Med 1973; 289: 1372. 